\title{
Safety in the housing of horses
}

\author{
A. Checchi, ${ }^{1}$ S. Casazza ${ }^{2}$ \\ ${ }^{1}$ University of Bologna, Dept. of Agri-Food Science and Technology, Bologna, Italy; \\ ${ }^{2}$ Expert professional for safety in working environments, ASH srls, Brugherio (MB), Italy
}

\begin{abstract}
Safety within an equestrian facility is given also by the sizes of the places in which horses are lodged. The stalls are considered to be the basic modular element of breeding and hosting places, but in Italy there are no specific references about the most appropriate surface related both to different breeds and safety of the workers taking care of them. We sought to determine the size of individual spaces, based on the height at the withers of horses, and to formulate a specific forming and informing course for employees on the likely risks of contact which could generate traumatic events.
\end{abstract}

\section{Introduction}

The safety within an equestrian structure is also given by the size of spaces for stabling of horses. The stalls are considered the minimal units for housing and, for this reason, have been very often the subject of discussion. It's important to keep in mind that the welfare, safety and serenity of the horses are the starting point for the safety of the people working with and around them.

In the regulatory framework there is no reference document defining the most appropriate surface for proper housing of horses, and old bibliography does not respond to all the needs related to the size of animals of different breed and size.

\section{Materials and methods}

The Ministry of Health with "The Code for the Protection of the Horse" recently gave instructions about and showed some minimum parameters in the dimension of stalls:

Correspondence: A. Checchi, University of Bologna, Dept. of Agri-Food Science and Technology, Viale Fanin, 50, Bologna, Italy.

Tel. +39.051.2096101 - Fax +39.051.2096171.

E-mail: antonio.checchi@unibo.it

Key words: horses, farm risks, fire prevention

@C Copyright A.Checchi and S. Casazza, 2013

Licensee PAGEPress, Italy

Journal of Agricultural Engineering 2013; XLIV(s2):e150

doi:10.4081/jae.2013.s2.e150

This article is distributed under the terms of the Creative Commons Attribution Noncommercial License (by-nc 3.0) which permits any noncommercial use, distribution, and reproduction in any medium, provided the original author(s) and source are credited.

$\begin{array}{lll}\text { Horses } & 3,00 \mathrm{~m} . & 3,00 \mathrm{~m} . \\ \text { Ponies } & 2,80 \mathrm{~m} . & 2,80 \mathrm{~m} . \\ \text { Mare\&foal delivery boxes } & 3,00 \mathrm{~m} . & 4,00 \mathrm{~m} .\end{array}$

On another side, the Scottish Animal Health and Welfare Act 2006 (the "“Act"), states that anyone who owns or operates an animal has a legal obligation to ensure his well-being and has the duty to treat him according to the "Five Freedoms" the first of which is given below:

"Freedom from discomfort ensuring an appropriate environment, including shelter and a comfortable resting area."

Starting from these two codes, we tried to introduce simple formulas that allow you to determine the size of individual spaces, estimated on the height at the withers of the subjects accommodated.

This does not mean that you should have different sizes of stalls for each horse depending on their size, but it does give directions, especially to farmers and horse riding schools. That is, for example, if you breed Haflinger horses or Frisian is should prepare boxes of different sizes, as well as if you are managing a pony school, needs will be different from a school that uses only horses.

To calculate stalls' dimensions, the area to be attributed to the relaying of each individual equine, with height at withers (hg) which can vary from $0.9 \mathrm{~m} .2 .0 \mathrm{~m}$., refers to the following formula:

$$
4 \times(\mathrm{hg}) 2
$$

Similarly, in the case where the stalls are not square, the minimum width of the front of the stall can be defined, where the access door will be positioned:

$$
1.8 \times(\mathrm{hg})
$$

The minimum ceiling height is important, on the one hand because of the risk of injury for equines bumping their head and, secondly, because it limits the amount of air circulating in the stable and thus influences its climatic conditions. Consequently, the recommended height of the lowest point is equal to twice the height at withers:

$$
2 \times(\mathrm{hg})
$$

If it is planned to accommodate within the structure mares with foal, as they need more space to assure a correct movement of the foal, we must follow the formula:

$$
5.2 \times(\mathrm{hg}) 2
$$

The stall for stallions must be wider than the others, because they because they move more inside the stall, then you can consider the appropriate formula:

$$
5.6 \times(\mathrm{hg}) 2
$$

\section{Interior features of stalls and accessories}

\section{Walls}

All four walls of the stall must be closed from the bottom to a height equal to $\mathrm{hg}<\mathrm{hp}<1.5 \mathrm{~m}$ where $\mathrm{hp}$ is the height of the wall. They must be strong enough to withstand kicks and sudden movements, must be anchored in stable way to the ground, so to support the weight of the animal in case he leans against them. This is important especially in the case of prefabricated structures that are usually positioned for 
short periods, such as at trade shows, competitions and other temporary events. In addition to what is indicated, the walls must not have protrusions, either internally or externally, and if in the upper part have a grid, this should not allow the passage of the limbs.

\section{Doors}

The access door to the stall must have a minimum width of $1.5 \mathrm{~m}$, because we must consider the transverse width of the body of man and horse, and a height not less than $2.5 \mathrm{~m}$.

The door must open towards the outside of the stall or scroll on a top rail.

Generally the doors are made of two parts, a closed lower one, which must have a height proportional to the withers of the animal (the standard ones, considering an average size at the withers equal to 1.60 to $1.70 \mathrm{~m}$, are about $1.30-1,40 \mathrm{~m}$.) and a top part that can be opened (this solution is mainly used in box with outer lane) or fixed, both filled or with grids. The opening of the top part in stables with an inside lane has some advantages but also some disadvantages related to the cleaning and maintenance of the lane. In fact, while the horse is eating he can dirty the outside of the stall, looking out during chewing and may interfere with the passage of the operators and users sticking out with the neck. However, there is the undeniable advantage that the possibility of extending his outside of the box allows the horse visual distraction and can so socialize with other horses. The best solution is that the upper grids can be opened, so you can close it during meal times and while the staff is working and leave it open in other moments so that the horse can "snoop" around.

\section{Windows}

The arrangement, number and size of windows are subject to the number of horses housed and the internal layout of the stable: their main function is to ensure adequate light and air circulation. Within each stable the air-entraining and illuminating ratio, i.e. the ratio between the windowed surface and that of the floor must be at least $1 / 10$. Beware that not always illuminating windows can be opened, so when calculating the above-mentioned parameter you must take into account only the windows that you can open.

If positioned on the wall, opposite the door, it allows the horse to look outside the stall. In this case, the windows should have the possibility of being closed during the night or for other needs.

Their optimal position should be commensurate with the size of the horse at the withers; in this regard it is recommended to take as a reference the height of the lower shutter of the front door. This kind of window must have a height from the ground of $1.5-2.0 \mathrm{~m}$. and a width of at least $1.0 \mathrm{~m}$.

Other types of windows used in the stables are transom windows, placed at least $2.5 \mathrm{~m}$. from the soil. They must be oriented so that the incoming air flows toward the ceiling and never directly on the horse. However they have the disadvantage that the horse cannot see outside. The important advantage of this type of opening is that they allow, with a good air circulation, in any season, to eliminate the high levels of ammonia that accumulate inside the stall. The most common sizes are equal to $1.2-1.4 \mathrm{~m}$. wide and $0,70-0,90 \mathrm{~m}$. in height.

If it is not possible to have the elements just described, it's advisable to provide for the presence of skylights on the roof of the structure, at least one for each stall, in order to assure a regular air change and the elimination of harmful gases. Keep in mind, however, that the skylights, in case of snow, cannot be opened and will not give light and therefore should not be the only air-entraining and illuminating source.

\section{Accessories}

All stalls must have within them some specific allocations: specifically, the drinking trough and feeder.

Feeders are trays with a round shape with a capacity of 20-25 liters and rounded and reinforced top edges, fastened to the wall.

The troughs are drinking systems connected to the water mains. The water level can be regulated automatically or by pressure on an inner tongue. It is recommended that each one has a separate shut-off valve, operable in case of malfunction. It 's very important that the water supply pipes are arranged perpendicular to the floor, so that it is more difficult for the horse to lean or damage them with their teeth or, if possible, recessed in the wall or protected.

Both elements must be positioned, respect to the ground, in proportion to the height at withers of the horse according to the following formula:

$$
\text { hg } \times 0.70
$$

The drinking trough and feeder inside the stall should be placed in opposite corners, on the diagonal of the stall, so to force the horse to walk a few steps and have a clear separation of drinking from the action of eating. It's also advisable to place the feeder on the same side of the door, for greater comfort of the operator who distributes the feed.

\section{Conclusions}

This article deals with some important issues towards which particular attention has been addressed over the last few years: animal welfare and safety at the workplace. We propose the design of a stable according to the parameters related to the welfare of the horses stabled, bearing in mind that this system allows you to resize the stalls as well as all the other spaces for the detention of horses of any breed, presenting the advantage of readjusting all the spaces within them.

\section{Bibliography}

Brandizzi G., Carbone E. (2004) Building for Sport, UTET

A. Checchi (1992), Stables: a guide for the design and construction, Edagricole

Chiumenti R. (2004), Rural Construction, Edagricole

Devenuto L. (2012) - Elements for the design of a riding club: Guidelines and functional diagrams - final work of the Master's Degree in "Architectural Design Sport facilities"

Ministry of Health (2011), The Ministry of Health for the horse Standards, rules and protection projects

FVO - Federal Veterinary Office (2009), Minimum requirements for horse boxes

Wheeler E.F. (2006) - Horse stable and riding arena design - Blackwell 